\section{МОДЕЛЬ}

БІОЕНЕРГЕТИЧНОГО

КЛАСТЕРУ

ВИРОБНИЦТВА

БІОПАЛИВА 3

\section{СІЛЬСЬКО-}

ГОСПОДАРСЬКИХ

КУЛЬТУР ТА ВІДХОДІВ

\begin{abstract}
КАЛЕТНІК Г. М., доктор економічних наук, професор, академік НААН Украӥни, завідувач кафедри адміністративного менеджменту та альтернативних джерел енергії

ПРИШЛЯК Н. В., кандидат економічних наук, доцент кафедри адміністративного менеджменту та альтернативних джерел енергіï,
\end{abstract} Вінницький національний аграрний університет (м. Вінниця)

Реалізація кластерного підходу є досить актуальною у зв'язку з необхідністю забезпечення економічної та енергетичної безпеки держсави загалом і паливно-енергетичного комплексу країни зокрема. Перспективним напрямком зміцнення енергетичної безпеки держави є розвиток біоенергетики. Одними з головних проблем біоенергетики є нерівномірний розподіл і перерозподіл сировини та продукиії біоенергетики. Обидві проблеми найбільи чітко виявляються в територіальних аспектах. Але в той же час вони призводять до виникнення іншої серйозної проблеми - несистемності виробництва і реалізації продукції біоенергетики, a, отже, й неможливості впровадження і розвитку біоенергетики.

У статті розкрито таксономію кластерних формувань в економіці. Охарактеризовано питання можливості формування біоенергетичних кластерів виробництва біопалива з біоенергетичних культур $i$ відходів. Установлено, щзо основоположником кластерного підходу був А. Маршалл. Вивчено підходи до трактування поняття «кластер» провідних світових та вітчизняних науковців, а також міжнародних організацій. Окреслено загальну структуру кластеру та визначено групи взаємопов'язаних суб'єктів біоенергетичного кластеру. Сформовано модель територіального біоенергетичного кластеру виробництва біопалива з сільськогосподарських культур та відходів, визначено його особливості та реконфігурацію. Визначено переваги створення біоенергетичних кластерів. Побудовано матриию PEST аналізу формування біоенергетичних кластерів. Визначено основи державної підтримки біоенергетичних кластерів. Охарактеризовано Навчально-наукововиробничий комплекс «Всеукрайнський науково-навчальний консориіум» як приклад кластеру, щзо забезпечує розвиток біоенергетики. Визначено перспективи формування біоенергетичних кластерів із виробництва біопалива із сільськогосподарських культур та відходів в Украӥні.

Ключові слова: біоенергетика, біопалива, біоенергетичні культури, енергетична безпека, екологічна безпека, відходи, потенціал, кластери.

Рис.: 6. Табл.: 1. Літ.: 16. 


\title{
MODEL OF BIOENERGY CLUSTER FOR RENEWABLE FUELS MANUFACTURING FROM CROPS AND WASTE
}

\author{
KALETNIK Grygorii, \\ Doctor of Economic Sciences, Professor, \\ Academician of NAAS of Ukraine, \\ Head of the Department of Administrative \\ Management and Alternative Energy Sources
}

\author{
PRYSHLIAK Natalia, \\ Candidate of Economic Sciences, \\ Associate Professor of the Department of Administrative \\ Management and Alternative Energy Sources, \\ Vinnytsia National Agrarian University \\ (Vinnytsia)
}

The implementation of the cluster approach is quite relevant in connection with the need to ensure economic and energy security of the state in general and the fuel and energy complex of the country in particular. A promising area for strengthening the energy security of the state is the development of bioenergy. One of the main problems of bioenergy is the uneven distribution and redistribution of raw materials and products of bioenergy. Both problems are most clearly manifested in territorial aspects. But at the same time, they lead to another serious problem - the inconsistency of production and sale of bioenergy products, and hence the impossibility of implementation and development of bioenergy.

The article reveals the taxonomy of cluster formations in the economy. The question of the possibility of forming bioenergy clusters of biofuel production from bioenergy crops and wastes is described. It is established that the founder of the cluster approach was A. Marshall. Approaches to the interpretation of the concept of «cluster» of leading world and domestic scientists, as well as international organizations have been studied. The general structure of the cluster is described and the groups of interacting subjects of the bioenergy cluster are determined. The model of the territorial bioenergy cluster of biofuel production from agricultural crops and wastes is formed, its features and reconfiguration are determined. The advantages of creating bioenergy clusters are identified. All links of the cluster should increase the profitability and competitiveness of the industry's products, ensure the sale of bioenergy products and find the most optimal and most profitable options for the production and sale of products. A PEST matrix of analysis of bioenergy clusters formation is constructed. The main bases of state support of bioenergy clusters are determined. The All-Ukrainian Research and Training Consortium Educational Research and Production Complex is described as an example of a cluster that ensures the development of bioenergy. Prospects for the formation of bioenergy clusters for the production of biofuels from crops and waste in Ukraine are identified.

Key words: bioenergy, biofuels, bioenergy crops, energy security, ecological safety, waste, potential, clusters.

Fig.: 6. Table: 1. Lit.: 16.

\section{МОДЕЛЬ БИОЭНЕРГЕТИЧЕСКОГО КЛАСТЕРА ПРОИЗВОДСТВА БИОТОПЛИВА ИЗ СЕЛЬСКОХОЗЯЙСТВЕННЫХ КУЛЬТУР И ОТХОДОВ}


КАЛЕТНИК Г. Н., доктор экономических наук, профессор, академик НААН Украины, заведующий кафедрой административного менеджмента и альтернативных источников энергии

ПРИШЛЯК Н. В., кандидат экономических наук, доцент кафедры административного менеджмента и альтернативных источников энергии Винницкий национальный аграрный университет (2. Винница)

\begin{abstract}
Реализация кластерного подхода является весьма актуальной в связи с необходимостью обеспечения экономической и энергетической безопасности государства $в$ целом и топливно-энергетического комплекса страны в частности. Перспективным направлением укрепления энергетической безопасности государства является развитие биоэнергетики. Одними из главных проблем биоэнергетики есть неравномерное распределение u перераспределение сырья и продукции биоэнергетики. Обе проблемь наиболее четко проявляются в территориальных аспектах. Но в то же время они приводят к возникновению другой серьезной проблемь - несистемности производства и реализачии продукиии биоэнергетики, а значит невозможности внедрения и развития биоэнергетики.
\end{abstract}

В статье раскрыто таксономию кластерных формирований в экономике. Охарактеризовань вопросы о возможности формирования биоэнергетических кластеров производства биотоплива биоэнергетических культур и отходов. Установлено, что основателем кластерного подхода был А. Маршалл. Изучены подходы к трактовке понятия «кластер» ведущих мировых и отечественных ученых, а также международных организачий. Очерчено общую структуру кластера и определень группы взаимодействующих субъектов биоэнергетического кластера. Сформирована модель территориального биоэнергетического кластера производства биотоплива из сельскохозяйственных культур и отходов, определеньл его особенности и реконфигурачия. Отмечено преимущества создания биоэнергетических кластеров. Построено матрииу PEST анализа формирования биоэнергетических кластеров. Определены основные базисы государственной поддержки биоэнергетических кластеров. Охарактеризовань Учебно-научно-производственньй комплекс «Всеукраинский научноучебный консорииум» как пример кластера, обеспечивающего развитие биоэнергетики. Определены перспективы формирования биоэнергетических кластеров по производству биотоплива из сельскохозяйственных культур и отходов в Украине.

Ключевые слова: биоэнергетика, биотоплива, биоэнергетические культуры, энергетическая безопасность, экологическая безопасность, отходы, потенциал, кластеры.

Рис.: 6. Табл.: 1. Лит.: 16.

Постановка проблеми. На сучасному етапі розвитку економіки України, що характеризується посиленням власної енергонезалежності та диверсифікацією паливно-енергетичного сектору 3 акцентом на інтегрування відновлюваної енергетики значна увага приділяється вивченню питань розвитку біоенергетичного потенціалу аграрного сектору. Гарантування національної енергетичної безпеки - одна з основних засад енергетичної стратегії України.

Аналітичні дослідження біоенергетичного потенціалу агропромислового сектору та можливості його інтеграції в паливно-енергетичний сектор України $є$ 
основою для подальшого розвитку енергетичної та аграрної галузей i впровадження елементів сталого розвитку у їхню організаційно-економічну діяльність.

Необхідність створення організаційно-економічних умов для ефективного розвитку галузі біоенергетики на основі ресурсної бази сільського господарства зумовлена, насамперед, зміцненням енергетичної безпеки держави [14, с. 124]. Водночас постає питання пошуку шляхів посилення конкурентоспроможності аграрного сектору економіки в умовах обмеження доступу до зовнішніх ринків збуту продукції, підвищення цін на енергоресурси та залежності від країнімпортерів нафти i природного газу, які несуть загрози енергетичному та економічному суверенітету держави. Окрім того, енергетична безпека має тісні причинно-наслідкові зв'язки як 3 економічною безпекою та розвиненістю держави, iї ресурсним потенціалом, так із національною безпекою загалом.

У зв'язку із зазначеним, перспективним предметом дослідження є кластери та державна кластерна політика. Кластерний підхід як інструмент підвищення конкурентоспроможності функціонування окремих секторів економіки достатньо грунтовно висвітлюється в економічних науках.

Аналіз останніх досліджень і публікацій. А. Маршалл [4, с. 116] був першим, хто почав розглядати кластери при вивченні особливостей промислових регіонів. Вчений відзначив тенденцію до концентрації спеціалізованих компаній у таких регіонах. Теорія А. Маршалла, де підвищену ефективність через близькість подібних компаній називали «зовнішньою економікою», заклала основу кластерної теорії.

Професор Гарвардської школи Майкл Портер визнаний основоположником кластерної теорії. На думку М. Портера [5, с. 78], кластери $\epsilon$ організаційною формою консолідації зусиль зацікавлених сторін, спрямованих на досягнення конкурентних переваг в умовах формування постіндустріальної економіки. Майкл Портер вважав, що головною перевагою кластерної моделі $\epsilon$ те, що перспективні конкурентні переваги створюються не ззовні, а на внутрішніх ринках, що дає можливість позитивно впливати на безпеку та стабільність економічного зростання країни.

Міжнародні організації також внесли свій внесок у визначення кластеру. Організація Об'єднаних Націй $з$ промислового розвитку (UNIDO) визначає кластер як «географічну концентрацію взаємопов'язаних підприємств та асоційованих установ, які стикаються із загальними проблемами та можливостями» [7]. Свропейська комісія дає подібне визначення цієї категорії: «Кластери - це групи спеціалізованих підприємств - часто малі і середні підприємства - та інші пов'язані допоміжні суб'єкти, які тісно співпрацюють у певному місці».

А. П. Бурковський вважав, що у загальній моделі виробничокоопераційних взаємодій суб'єктів господарювання важливою рисою кластеру є чинник інноваційної орієнтованості. У переважній більшості кластери формуються там, де здійснюється або очікується «інноваційний прорив» у галузі техніки й технології виробництва та подальшого виходу на нові ринки [9, с. 68].

У сучасних економічних процесах провідні позиції займають кластери та 
системи взаємовідносин між фірмами та організаціями [6, с. 20]. Головною метою кластеру $є$ підвищення конкурентоспроможності своїх членів на внутрішньому та зовнішньому ринках за допомогою комерційного та некомерційного співробітництва, науково-дослідної та інноваційної діяльності, освіти, тренінгів та заходів із підтримки політики з максимальним врахуванням ринкового механізму. Найвища ефективність кластерів досягається тоді, коли вони створюються за ініціативою знизу вгору, тобто коли самі компанії для підвищення своєї конкурентоспроможності розуміють необхідність об'єднання в кластер [2, с. 480].

I. В. Гончарук організаційно кластери у виробництві біопалива позиціонує як інституційні моделі консолідації ресурсів для досягнення передумов енергетичної незалежності агропромислового комплексу. Енергетична незалежність агропромислового комплексу щодо їі ролі у реалізації засад сталого розвитку розглядається як цільовий орієнтир розвитку цієї сфери господарювання у поєднанні із засадами досягнення продовольчої безпеки, виконання інших функцій, притаманних сільському господарству [11, с. 64].

Задля дослідження моделі біоенергетичного кластеру виробництва біопалива із сільськогосподарських культур та відходів існує потреба у більш точній концептуалізації того, що виражають кластери або кластерні об'єднання та пов'язані з ними явища.

Формулювання цілей статті. Метою дослідження $\epsilon$ теоретикометодологічне обгрунтування та методологічне вдосконалення основ організації біоенергетичного кластеру 3 виробництва біопалива із сільськогосподарських культур та відходів.

Виклад основного матеріалу дослідження. Евристичною основою розвитку біоенергетичного сектору у середньо- та довгостроковій перспективі та зміцнення енергетичної незалежності економіки України $\epsilon$ створення біоенергетичних кластерів за сукупністю ознак, що мають найбільшу питому вагу у загальному розвитку цього сектору.

3 огляду на вище зазначене, можна визначити біоенергетичний кластер як територіальну організаційно-виробничу форму інтеграції взаємопов'язаних суб'єктів господарювання, банківського, приватного сектору, освітніх закладів, органів влади та суміжних, допоміжних, конструкторських, інноваційних підприємств/організацій, об'єктів інфраструктури, що характеризуються виробництвом біоенергетичної сировини, побічних продуктів, відходів та біопалива $[9$, с. $67 ; 13$, с. 54]. Біоенергетичний кластер характеризується наявністю погодженої стратегії розвитку, спрямованої на реалізацію інтересів кожного з учасників кластеру, і що має істотну продовольчу, соціальноекономічну та енергетичну значимість для регіону. Подібні об'єднання сприятимуть збільшенню можливостей для впровадження технологічних інновацій у сфері біоенергетики і полегшуватимуть протистояння наявним перешкодам для розвитку біоенергетичного сектору та біоорієнтованої економіки.

Таким чином, складовими елементами біоенергетичного кластеру можуть бути сільськогосподарські підприємства (як виробники біоенергетичної 
сировини, продовольчої сировини, побічної сировини та відходів); зацікавлені суб'єкти у розвитку біоенергетики (виробники усіх видів біопалива та біоенергіi); суб'єкти обслуговуючої інфраструктури; освітні заклади, науководослідницькі центри, бізнес-інкубатори; допоміжні об'єкти (консалтингові, лізингові, юридичні, інвестиційно-інноваційні підприємства). Важливою ланкою при утворенні та функціонуванні кластеру, яка певною мірою може впливати на структуру кластеру та його розвиток, $є$ влада в особі державних органів у регіоні та органів місцевого самоуправління.

Загальна структура кластеру - це модель побудови коопераційних зв'язків між суб'єктами об'єднання. Розглянемо основні групи взаємопов'язаних суб'єктів біоенергетичного кластеру (рис. 1).

\begin{tabular}{|c|c|c|}
\hline Група 1 & Ядро кластеру & $\begin{array}{l}\text { Сільськогосподарські підприємства - виробники сировини, } \\
\text { локалізовані на території, згруповані за видами основної } \\
\text { продукції або за підгалузями; } \\
\text { біоенергетичні підприємства - виробники біопалива. }\end{array}$ \\
\hline Група 2 & $\begin{array}{l}\text { Постачальники } \\
\text { підприємств } \\
\text { кластера }\end{array}$ & $\begin{array}{l}\text { Постачальники насіння, добрив, техніки, обладнання, } \\
\text { обслуговуючі компанії. }\end{array}$ \\
\hline Група 3 & $\begin{array}{l}\text { Споживачі } \\
\text { підприємств } \\
\text { кластеру }\end{array}$ & $\begin{array}{l}\text { Внутрішнє споживання продовольчої сировини та } \\
\text { відновлюваних енергоресурсів, міжрегіональні доставки, } \\
\text { експорт. }\end{array}$ \\
\hline Група 4 & $\begin{array}{l}\text { Підтримувальна } \\
\text { інфраструктура }\end{array}$ & $\begin{array}{l}\text { Адміністративна підтримка, фінансові, складські та } \\
\text { транспортні послуги. }\end{array}$ \\
\hline Група 5 & $\begin{array}{l}\text { Науково- } \\
\text { технічний } \\
\text { розвиток }\end{array}$ & $\begin{array}{l}\text { Освітні заклади, науково-дослідницькі інститути, дослідні } \\
\text { станції, бізнес-інкубатори, інноваційні хаби. }\end{array}$ \\
\hline Група 6 & $\begin{array}{l}\text { Інституційне } \\
\text { забезпечення }\end{array}$ & $\begin{array}{l}\text { Державні та регіональні органи влади, податкові служби та } \\
\text { інші контролюючі об’єкти. }\end{array}$ \\
\hline
\end{tabular}

\section{Рис. 1. Групи взаємопов'язаних суб'сктів біоенергетичного кластеру}

Джерело: розроблено авторами

Наразі використання біоенергетичних ресурсів у ролі сировини для виробництва біопалива в Україні набуває все більшої популярності та розповсюдження. Це пояснюється здорожчанням традиційних енергоресурсів (природного газу, нафти, електроенергіi); бажанням споживачів використовувати екологічно чисту енергію, наявністю побічних продуктів та відходів у виробників (солома, тирса, гній та ін.). Водночас існує низка факторів, що стримують широкомасштабне використання біоенергетичного потенціалу як енергоресурсу, зокрема, недостатня ефективність технологічного забезпечення процесу виробництва палива 3 урахуванням специфіки біомаси, яка використовується; незацікавленість споживачів у переході на біопалива; недосконалість нормативно-правового регулювання сфери біоенергетики; відсутність напрацьованих логістичних схем. 
Створення спеціалізованого біоенергетичного кластеру виробництва біопалива із сільськогосподарських культур та відходів було б здатне забезпечити максимальну ефективність використання природо-ресурсного потенціалу (земельних площ, сировини, побічної продукції, відходів), забезпечити споживачів екологічно чистими енергоресурсами i, водночас, виконувало $\sigma$ роль фактора інноваційного розвитку, який сприяв би переорієнтації на інноваційну модель розвитку регіонів.

Беручи до уваги вищенаведене, нами було запропоновано модель територіального біоенергетичного кластеру виробництва біопалива iз сільськогосподарських культур та відходів (рис. 2).

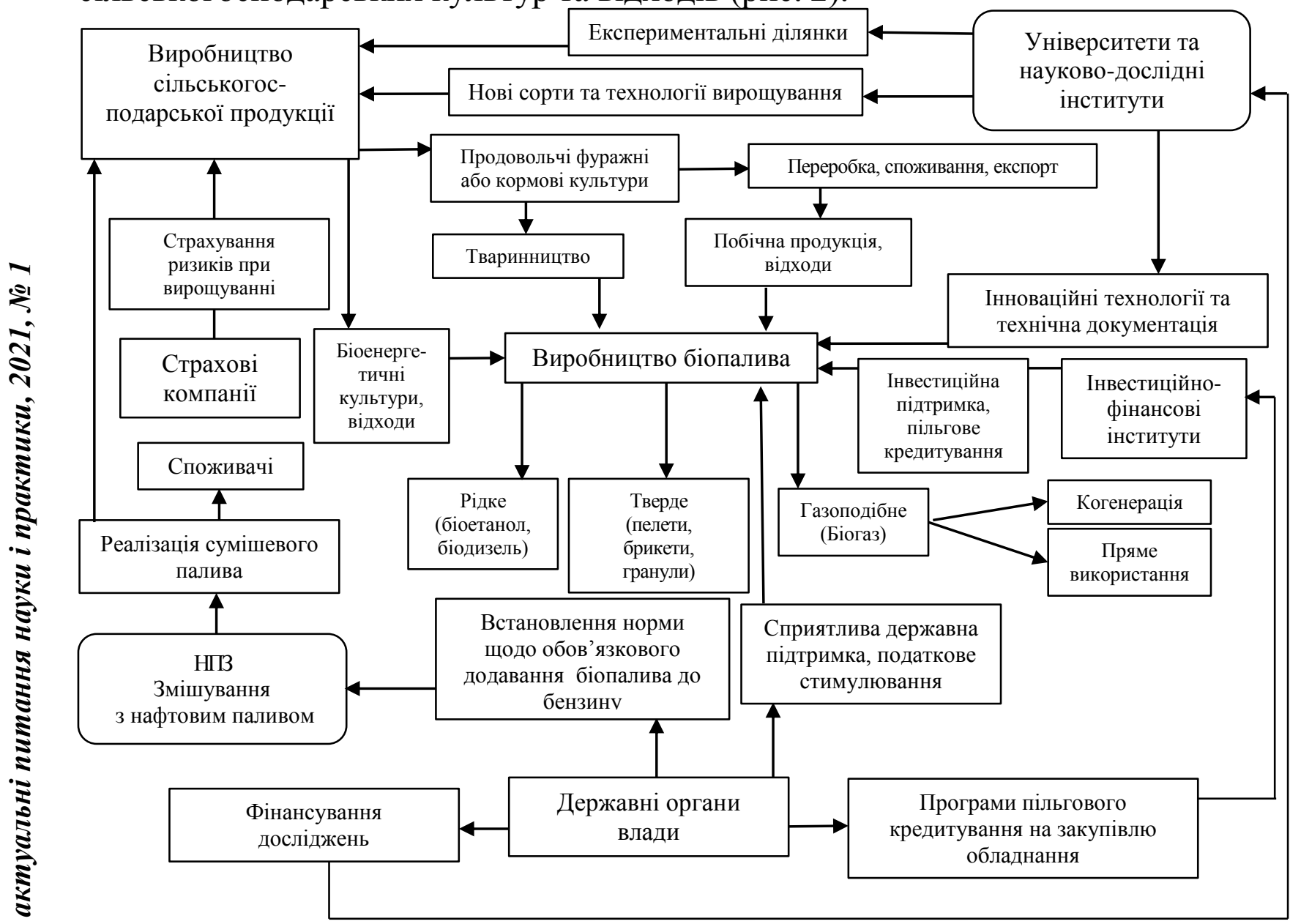

\section{Рuc. 2. Модель територіального біоенергетичного кластеру виробництва біопалива із сільськогосподарських культур та відходів}

Джерело: розроблено авторами

При збільшенні обсягів виробництва біопалива важливо враховувати необхідність балансу використання сільськогосподарських культур як біоенергетичної сировини і як продовольчої продукції (у т.ч. кормів для тварин). Адже надзвичайно важливо забезпечувати як енергетичну, так і продовольчу безпеку. Їх взаємопов'язаність і взаємовплив при використанні сільськогосподарських культур не можна недооцінювати. Враховуючи обсяги виробництва сільськогосподарської продукції на сьогодні, можна підкреслити, що Україна не лише виробляє достатню кількість продуктів харчування, а й спрямовує частину їх обсягу на експорт. 
Важливим $є$ і те, що Україна $є$ аграрною державою, і це вкотре підкреслює переваги України перед іншими країнами щодо розвитку біоенергетичних кластерів. Значні площі сільськогосподарських угідь, що зараз виведені 3 експлуатації і не використовуються, висока урожайність культур, зацікавленість національних виробників та зростання попиту на біопаливо створюють сприятливий клімат для розвитку біоенергетичних кластерів в Україні.

Задля розвитку біоенергетичного потенціалу України та, як наслідок, біоекономіки як нового напрямку в економіці, ідея створення біоенергетичних кластерів $є$ новим підходом до ведення не тільки економіки регіону, а й національної економіки. У світовій практиці доходять висновку, що рівень рентабельності сільського господарства залежатиме саме від рівня впровадження у регіонах агро-біоенергетичних кластерів [15, с. 230].

Кластерний підхід дозволяє підвищити ефективність взаємодії виробників сільськогосподарської продукції, переробних підприємств, виробників «зеленої» енергії, приватного сектору, фінансових інститутів, держави, дослідницьких та освітніх установ в інноваційному процесі. Відтак створення біоенергетичного кластеру виробництва біопалива 3 сільськогосподарських культур та відходів матиме низку переваг для усіх учасників кластеру. Основні переваги біоененергетичного кластеру наведено на рис. 3.

\begin{tabular}{|c|c|}
\hline 1 & $\begin{array}{l}\text { розвиток агробіо- і харчових технологій, забезпечення здорового харчування населення на } \\
\text { основі біоекономічних методів і підходів; }\end{array}$ \\
\hline 2 & $\begin{array}{l}\text { підвищення ефективності системи доставок сировини, компонентів і комплектуючих } \\
\text { всередині кластеру; }\end{array}$ \\
\hline 3 & $\begin{array}{l}\text { поліпшення зовнішньоекономічної інтеграції та зростання конкурентоспроможності } \\
\text { учасників завдяки включенню кластеру і його учасників у глобальний ланцюжок створення } \\
\text { доданої вартості; }\end{array}$ \\
\hline 4 & $\begin{array}{l}\text { спрощення доступу учасників кластеру до фінансових ресурсів внаслідок створення } \\
\text { інтегрального інвестиційного портфеля; }\end{array}$ \\
\hline 5 & $\begin{array}{l}\text { впровадження інноваційних } \\
\text { висококваліфікованих фахівців. }\end{array}$ \\
\hline
\end{tabular}

Рис. 3. Переваги створення біоенергетичних кластерів

Джерело: розроблено авторами за даними [1, 3, 6]

Ідентифікація й визначення переваг потенційного кластеру в кожній галузі $€$ різними, оскільки кожний вид кластерних об'єднань має свої особливості, можливості, пріоритети економічного зростання, а також певні характеристики, притаманні учасникам кластеру.

Як показує світовий досвід, кластерні об’єднання $є$ однією 3 найефективніших форм організації інноваційних процесів, поліпшення соціально-економічного розвитку регіонів, підвищення якості науково-технічних розробок та інновацій, зростання ефективності використання природоресурсного потенціалу, зміцнення конкурентоспроможності та обороноздатності країни, оскільки на ринку конкурують вже не окремі підприємства, а їх 
сукупність, які скорочують свої витрати завдяки спільному технологічному ланцюгу та кооперації компаній.

В умовах України біоенергетичні кластери доцільно розглядати як якісно нову форму управління та організації комплексної виробничої діяльності, а також як важливу складову імплементації інноваційної моделі економічного розвитку регіонів 3 урахуванням специфіки українських економічної та управлінської систем, а також забезпечення відповідної законодавчонормативної підтримки [10, с. 28].

Враховуючи перспективи розвитку біоенергетики в Україні, варто зазначити, що створення кластерного об'єднання підприємств у цій галузі було б значним досягненням, посилило б конкурентоспроможність учасників кластеру і стало б запорукою підвищення національної енергетичної безпеки. Біоенергетичний кластер виробництва біопалива iз сільськогосподарських культур та відходів створюється при сприятливому сполученні як позитивних, так і негативних факторів.

Для узагальнення всіх позитивних та негативних політичних, економічних, соціальних та технологічних факторів, що впливають на формування біоенергетичного кластеру, ми можемо представити матрицю PEST аналізу (табл. 1).

Емпіричні дані свідчать про те, що впровадження інноваційних біоенергетичних кластерів $\epsilon$ неможливим без сприятливого інвестиційного клімату та стабільної державної підтримки, яка б інтегрувала політико-правові, фінансові, науково-технологічні, комунікативні інструменти, спрямовані на створення належних умов для розвитку інноваційних процесів, стимулювання впровадження результатів інноваційної діяльності у виробництво.

Державна підтримка біоенергетичних кластерів повинна формуватися на базі таких блоків: формуючий, регулюючий, реалізуючий, контролюючий (рис. 4).

Водночас при формуванні кожного блоку потрібно враховувати основні принципи державної підтримки інноваційних кластерів, зокрема комплексності, адресності, легітимності, об’єктивності та еквівалентності.

Серед різноманітних підходів до організації та функціонування кластерів провідними завжди вважалися процеси взаємодії бізнесу і влади. На місцеві органи управління покладається місія вдосконалення інфраструктури для потреб інноваційного бізнесу та координації взаємодії в межах створюваного інноваційного формування.

Екзистенція та розвиток кластерів у більшості країн світу забезпечуються за рахунок різних прямих та непрямих методів державної підтримки, які стимулюють регіональний розвиток через збільшення зайнятості, відрахувань у бюджети різних рівнів, підвищення рівня оплати праці, стійкості й конкурентоспроможності регіонального виробництва. Державна підтримка інноваційних кластерів у різних країнах світу здебільшого спрямована на активізацію науково-технічної діяльності кластерів шляхом збільшення фінансування їхньої інноваційної діяльності; створення високотехнологічної конкурентоспроможної продукції; випуску продукції, що враховує кон’юнктуру 
світового ринку; інтегрування наукових досліджень і розробок до світової інноваційної системи та сприяння міжнародному партнерству у сфері інноваційної діяльності [13, с. 55].

Таблиия 1

Матриця PEST-аналізу формування біоенергетичних кластерів

\begin{tabular}{|c|c|}
\hline Політичні & Економічні \\
\hline $\begin{array}{l}\text { Позитивні } \\
\text { 1. Активність молодих та висококваліфікованих кадрів } \\
\text { та амбіційність щодо створення позитивних } \\
\text { перетворень; } \\
\text { 2. Ефективна політика унапрямку децентралізації; } \\
\text { 3. Підтримка міжнародних організацій та країн- } \\
\text { партнерів; } \\
\text { 4. Свропейський вектор розвитку та готовність до } \\
\text { адаптації українського законодавства до вимог ЄС; } \\
\text { 5. Зміни у законодавстві, що сприяють посиленню } \\
\text { боротьби з корупцією, зменшення бюрократизації. } \\
\text { 1. Недосконалість нормативної бази у сфері } \\
\text { біоенергетики; } \\
\text { 2. Політична нестабільність та наслідки революційних } \\
\text { подій; } \\
\text { 3. Військовий конфлікт на сході України та анексія } \\
\text { Криму; } \\
\text { 4. Бюрократизація, корупція та лобіювання інтересів } \\
\text { окремих політичних груп. }\end{array}$ &  \\
\hline Соціальні & Технологічні \\
\hline $\begin{array}{l}\text { Позитивні } \\
\text { 1. Наявність трудових ресурсів та кваліфікованої } \\
\text { робочої сили; } \\
\text { 2. Високий рівень середньої та вищої освіти в країні. } \\
\text { Негативні } \\
\text { 1. Старіння нації, збільшення кількості людей похилого } \\
\text { віку; } \\
\text { 2. Міграційні процеси, від’їд працездатного населення } \\
\text { та молоді за кордон; } \\
\text { 3. Урбанізація; } \\
\text { 4. Проблеми з пошуком роботи у сільській місцевості; } \\
\text { 5. Повільний розвиток інфраструктури у сільській } \\
\text { місцевості; } \\
\text { 6. Низький рівень доходів населення та низька } \\
\text { купівельна спроможність до впровадження нових } \\
\text { технологій (наприклад індивідуальних біогазових } \\
\text { установок, сонячних батарей). }\end{array}$ & $\begin{array}{l}\text { Позитивні } \\
\text { 1. Автоматизація та механізація всіх виробничих } \\
\text { процесів, швидкі темпи розвитку науково-технічного } \\
\text { прогресу, наявність «ноу-хау»; } \\
\text { 2. Зміцнення захисту прав інтелектуальної власності; } \\
\text { 3. Технологічна спорідненість певних суб’єктів } \\
\text { господарювання, які функціонують заради спільного } \\
\text { кінцевого результату; } \\
\text { 4. Географічна близькість низки суб'єктів } \\
\text { господарювання, які технологічно та економічно } \\
\text { пов'язані між собою; } \\
\text { 5. Розвиненість комунікаційних та інформаційних } \\
\text { технологій. } \\
\text { 1. Відсутність зв’язку між наукою та технологією в } \\
\text { реальному секторі економіки; } \\
\text { 2. Відставання освіти у вищій школі від інноваційних } \\
\text { процесів; } \\
\text { 3. Недостатня увага та нестача фінансової підтримки } \\
\text { державою науки та інновацій; } \\
\text { 4. Невідповідність певної виробленої продукції у } \\
\text { сфері біоенергетики світовим стандартам, недостатнє } \\
\text { врахування кон'юнкури світового ринку. }\end{array}$ \\
\hline
\end{tabular}

Джерело: сформовано авторами за даними [8, 12] 


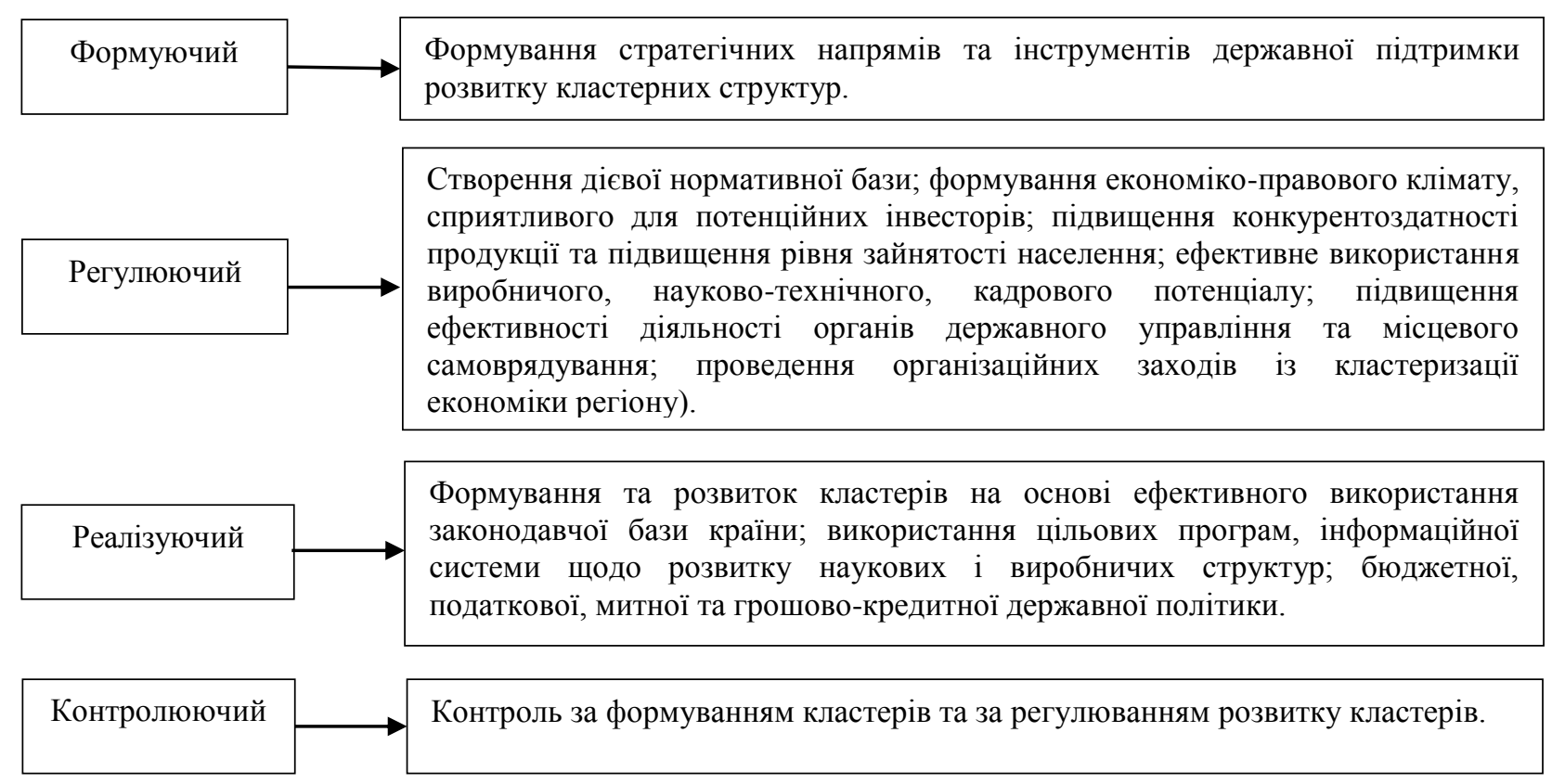

\section{Puc. 4. Основи державної підтримки біоенергетичних кластерів \\ Джерело: удосконалено авторами на основі опрачьованої літератури [13, с. 54]}

Найбільш значущою є державна підтримка на етапі не створення, а розвитку кластеру, оскільки вплинути на бажання потенційних учасників стати членами кластеру досить складно, а створення стимулюючих та сприятливих умов потребує значних фінансових ресурсів. На етапі розвитку кластеру, коли він вже довів свою життєздатність, державна підтримка може стати стимулюючим важелем для його розвитку.

Подальшими заходами державної підтримки розвитку біоенергетичних кластерів мають бути такі, які забезпечать рівний доступ учасників на ринок сировини та біопалива; підтримку виробництва та використання вітчизняного біоенергетичного обладнання; забезпечення державної підтримки наукових досліджень та формування сприятливого інституційного клімату щодо впровадження проектів прогресивних біоенергетичних технологій.

Ефективне впровадження усіх етапів державної стратегії у напрямку розвитку біоенергетичних кластерів прискорить очікуваний результат щодо збільшення їхньої кількості в Україні та продемонструє позитивний вплив біоенергетичних кластерів на економічне зростання, посилення енергетичної безпеки та поліпшення екологічної ситуації.

Важливим є також дотримання певних етапів щодо впровадження моделі біоенергетичного кластеру. Зокрема, важливим $є$ виявлення конкурентоспроможних підприємств - потенційних учасників кластеру, пошук можливостей щодо залучення інвестицій; визначення взаємовідносин між учасниками інноваційного процесу; проведення економіко-статистичного моделювання ефективності діяльності майбутнього кластеру.

Яскравим прикладом кластеру, що забезпечує розвиток біоенергетики $\epsilon$ Навчально-науково-виробничий комплекс «Всеукраїнський науково-навчальний консорціум» (далі - Консорціум), засновниками якого $є$ Вінницький 
національний аграрний університет, Інститут біоенергетичних культур i цукрових буряків НААН України і Інститут Продовольчих ресурсів НАAН України. Склад Консорціуму розширювався 3 моменту його створення i збільшував свою дослідницьку базу (рис. 5).

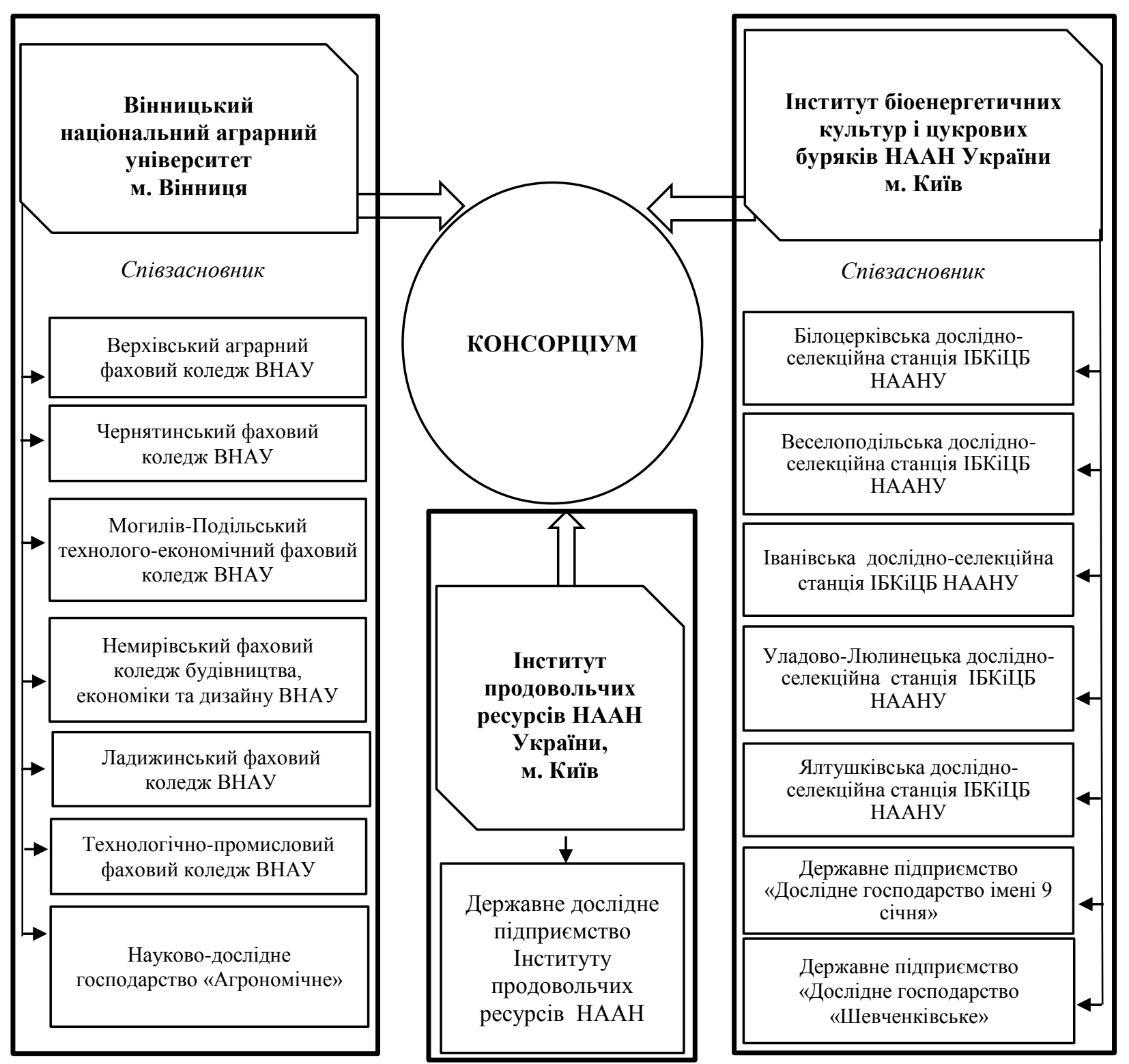

Рис. 5. Організаційна структура ННВК «Всеукраїнський науковонавчальний консорціум»

Джерело: сформовано автором за даними [16]

Головною метою діяльності Консорціуму є єдина координація діяльності його засновників з підвищення ефективності проведення наукових досліджень, у тому числі у галузі біоенергетики; організація, проведення і координація прикладних наукових досліджень у сфері агропромислового комплексу України; формування сучасної ефективної системи підготовки, перепідготовки та підвищення кваліфікації фахівців з вищою освітою для аграрної галузі на основі інтеграції та спільної діяльності наукового, навчального, інноваційного та технологічного потенціалу засновників Консорціуму. У своїй діяльності 
засновники використовують і враховують національний та світовий досвід та передові технології.

Значна частина наукової діяльності Консорціуму пов'язана 3 дослідженням ефективності вирощування та переробки біоенергетичних культур та відходів на виробництво біоенергії (рис. 6).

Основні наукові напрями роботи Консорціуму

стимулювання розробки адаптованих технологій вирощування біоенергетичних культур i цукрових буряків;

економічна ефективність виробництва та використання біопалив в Україні;

розробка нових енергоефективних, ресурсоощадних технологій у рослинництві і тваринництві;

створення i впровадження високопродуктивних та економічних машинно-транспортних агрегатів;

розробка екологічно чистих (органічних) технологій вирощування основних сільськогосподарських культур відповідно до міжнародних програм отримання екологічно безпечної органічної продукції;

розробка науково-прикладних основ трансформування організаційно-економічних відносин до соціально зорієнтованих ринкових умов в агропромисловому комплексі.

\section{Рис. 6. Основні наукові напрямки роботи ННВК «Всеукраїнський науково- навчальний консорціум» \\ Дюерело: сформовано автором за даними [16]}

Консорціум має значний науково-освітянський потенціал: 91 доктор наук, 405 кандидатів наук, забезпечується навчальний процес на 38 спеціальностях, 74 освітніх програмах підготовки молодших спеціалістів, бакалаврів, магістрів, 25 спеціальностях підготовки докторів філософії, 13 спеціальностей захисту кандидатських та докторських дисертацій, 11 фахових періодичних наукових видань, 98 філії кафедр у дослідних господарствах та селекційних станціях, більше 18 традиційних щорічних міжнародних конференцій 3 питань продовольчої, екологічної, енергетичної та економічної безпеки України та світу.

Міжнародна співпраця із закордонними партнерами є необхідною умовою динамічного розвитку, підвищення іміджу Консорціуму та формування міждержавних кластерних зв'язків. Консорціум має налагоджену активну навчально-практичну та науково-дослідну співпрацю 355 університетами 3 понад 30-ти країн світу. Щорічно консорціум приймає понад 100 закордонних делегацій.

Світова практика доводить, що функціонування найбільш успішних економічних систем практично повністю забезпечується завдяки перевагам у технологіях виробництва й управління. Тому успішний розвиток економічної системи будь-якого рівня можливий за комплексного використання концепцій стратегічного управління з урахуванням процесів, які визначають специфіку сучасного етапу розвитку економіки. 
Висновки. Таким чином, на сучасному етапі економічного розвитку кластерні стратегії широко використовуються в усьому світі. Формуючи кластерну політику, доцільно пропагувати широку класифікацію кластерів 3 метою залучення до них більшої кількості учасників. У результаті проведеного нами дослідження встановлено:

1. Задля створення регіональних інноваційних мереж біоенергетичних кластерів доцільно створити робочу групу та розробити державну програму 3 організації біоенергетичних кластерів спільно із зацікавленими міністерствами та відомствами.

2. Задля підвищення динаміки зростання техніко-економічних показників діяльності біоенергетичних кластерів на державному рівні необхідно запровадити пряме фінансове стимулювання та надання пільгових державних кредитів, фінансування базових інновацій виробничого сектору, забезпечення інновацій у неринковому секторі, враховуючи досвід зарубіжних країн.

3. Діяльність енергетичних кластерів 3 виробництва біопалив із сільськогосподарських культур та відходів формує низку переваг, зокрема максимально ефективне використання сільськогосподарської сировини, побічної продукції та відходів, ефективну взаємодію органів влади, бізнес-структур та науково-дослідних установ, підвищення рівня ефективності малих та середніх підприємств, зміцнення енергетичної та екологічної безпеки держави.

\section{Список використаних джерел}

1. Kaletnik G., Pryshliak N. Bioenergy potential development of the agrarian sector as a component of sustainable development of Ukraine. Management mechanisms and development strategies of economic entities in conditions of institutional transformations of the global environment: col. monog. ISMA University. Riga: Landmark SIA, 2019. P. 96-104.

2. Kaletnik G., Pryshliak V., Pryshliak N. Public Policy and Biofuels: Energy, Environment and Food Trilemma. Journal of Environmental Management and $\begin{array}{llllll}\text { Tourism. } 2019 . & \text { Volume } & \text { X. Issue 3(35). } & \text { P. } & \text { 479-487. }\end{array}$ https://doi.org/10.14505/jemt.v10.3(35).01.

3. Kulyk M., Kalynychenko O, Pryshliak N., Pryshliak V. Efficiency of using biomass from energy crops for sustainable bioenergy development. Journal of Environmental Management \& Tourism. 2020. T. 11. №5. P. 1040-1053. https://doi.org/10.14505/jemt.v11.5(45).02.

4. Marshall A. Principles of economic science. Moscow: Progress. 1993. 226 p.

5. Porter M. Clusters and the new economics of competition. Harvard Business Review. 1998. Vol. 76. №6. P. 77-90.

6. Pryshliak N., Tokarchuk D. Socio-economic and environmental benefits of biofuel production development from agricultural waste in Ukraine. Environmental \& Socio-economic Studies. 2020. V. 8. №1. P. 18-27. https://doi.org/10.2478/environ2020-0003.

7. UNIDO (2001). Development of Clusters and Networks of SMEs: The UNIDO Programme. URL: http://www.unido.org/ doc/351428.htmls (дата звернення 18.01.2021). 
8. Zulauf C., Prutska O., Kirieieva E., Pryshliak N. Assessment of the potential for a biofuels industry in Ukraine. Problems and Perspectives in Management. 2018. №16. Issue 4. P. 83-90. http://dx.doi.org/10.21511/ppm.16(4).2018.08.

9. Бурковський А. П. Кластерна форма організації та механізм іiі дії в сучасних умовах господарювання. Вісник Кам'янець-Подільського національного університету імені Івана Огієнка. Економічні науки. 2012. № 6. C. 67-73.

10. Войнаренко М., Береза А. Кластерні об'єднання: міжнародний досвід та українські реалії. Економіст. 2013. №10. С. 27-30.

11. Гончарук I. В. Кластеризація виробництва біопалив у формуванні енергетичної незалежності агропромислового комплексу. Інвестииіï: практика та досвід. 2020. №19-20. С. 64-73.

12. Калетнік Г. М., Гончарук I. В., Смчик Т. В., Лутковська С. М. Аграрна політика та земельні відносини. Вінниця: ВНАУ, 2020. 307 с.

13. Комар Н. Концепція формування та державної підтримки кластерних структур в Свропі. Вісник Тернопільського національного технічного економічного університету. 2014. №2. С. 53-64.

14. Мельниченко В. В. Кластерне моделювання розвитку біоенергетичного потенціалу сільськогосподарських підприємств. Економіка та держава. 2018. №2. C. 124-128.

15. Талавиря М. П., Коваль О. М., Добрівська М. В. Розвиток біоенергетичного потенціалу в Україні. Вісник ХНАУ. Серія: Економічні науки. 2017. №3. C. 229-238.

16. Офіційний сайт Вінницького національного аграрного університету. URL: $\quad$ https://vsau.org/pro-universitet/nnvk-vseukraiinskij-naukovo-navchalnijkonsorczium (дата звернення 18.01.2021).

\section{References}

1. Kaletnik, G., \& Pryshliak, N. (2019). Bioenergy potential development of the agrarian sector as a component of sustainable development of Ukraine. Management mechanisms and development strategies of economic entities in conditions of institutional transformations of the global environment: col. monog. ISMA University. Riga: Landmark SIA, 2019, 96-104 [in English].

2. Kaletnik, G., Pryshliak, V., \& Pryshliak, N. (2019). Public Policy and Biofuels: Energy, Environment and Food Trilemma. Journal of Environmental $\begin{array}{lllll}\text { Management } \quad \text { Tourism, } & \text { X, 3(35), } & \text { 479-487. }\end{array}$ https://doi.org/10.14505/jemt.v10.3(35).01 [in English].

3. Kulyk, M., Kalynychenko, O., Pryshliak, N., \& Pryshliak, V. (2020). Efficiency of using biomass from energy crops for sustainable bioenergy development. Journal of Environmental Management \& Tourism, 11, 5, 1040-1053. https://doi.org/10.14505/jemt.v11.5(45).02 [in English].

4. Marshall, A. (1993). Principles of economic science. Moscow: Progress [in English].

5. Porter, M. (1998). Clusters and the new economics of competition. Harvard Business Review, 76, 6, 77-90 [in English]. 
6. Pryshliak, N., \& Tokarchuk, D. (2020). Socio-economic and environmental benefits of biofuel production development from agricultural waste in Ukraine. Environmental \& Socio-economic Studies, 8, 1, 18-27. Retrieved from: https://doi.org/10.2478/environ-2020-0003 [in English].

7. UNIDO (2001) "Development of Clusters and Networks of SMEs: The UNIDO Programme". unido.org. Retrieved from: http://www.unido.org/ doc/351428.htmls [in English].

8. Zulauf, C., Prutska, O., Kirieieva, E., \& Pryshliak, N. (2018). Assessment of the potential for a biofuels industry in Ukraine. Problems and Perspectives in Management, $16, \quad 4, \quad 83-90.4$ Retrieved http://dx.doi.org/10.21511/ppm.16(4).2018.08 [in English].

9. Burkovsky, A.P. (2012). Klasterna forma orhanizatsiyi ta mekhanizm yiyi diyi $\mathrm{v}$ suchasnykh umovakh hospodaryuvannya [Cluster form of organization and mechanism of its action in modern economic conditions]. Visnyk KamyanetsPodilskoho natsionalnoho universytetu imeni Ivana Ohiyenka. Ekonomichni nauky Bulletin of Kamyanets-Podilsky National University named after Ivan Ogienko. Economic sciences, 6, 67-73 [in Ukrainian].

10. Voynarenko, M., \& Bereza, A. (2013). Klasterni obyednannya: mizhnarodnyy dosvid ta ukrayinski realiyi [Cluster associations: international experience and Ukrainian realities]. Ekonomist - Economist, 10, 27-30 [in Ukrainian].

11. Honcharuk, I.V. (2020). Klasteryzatsiya vyrobnytstva biopalyv u formuvanni enerhetychnoyi nezalezhnosti ahropromyslovoho kompleksu [Clustering of biofuels production in the formation of energy independence of the agro-industrial complex]. Investytsiyi: praktyka ta dosvid - Investments: practice and experience, 1920, 64-73 [in Ukrainian].

12. Kaletnik, H.M., Honcharuk, I.V., Yemchyk, T.V., \& Lutkovska, S.M. (2020). Ahrarna polityka ta zemelni vidnosyny [Agrarian policy and land relations]. Vinnytsia: VNAU [in Ukrainian].

13. Komar, N. (2014). Kontseptsiya formuvannya ta derzhavnoyi pidtrymky klasternykh struktur v Yevropi [The concept of formation and state support of cluster structures in Europe]. Visnyk Ternopilskoho natsionalnoho tekhnichnoho ekonomichnoho universytetu - Bulletin of Ternopil National Technical Economic University, 2. 53-64 [in Ukrainian].

14. Melnychenko, V.V. (2018). Klasterne modelyuvannya rozvytku bioenerhetychnoho potentsialu silskohospodarskykh pidpryyemstv [Cluster modeling of development of bioenergy potential of agricultural enterprises]. Ekonomika ta derzhava - Economy and state, 2, 124-128 [in Ukrainian].

15. Talavyrya, M.P., Koval, O.M., \& Dobrivska, M.V. (2017). Rozvytok bioenerhetychnoho potentsialu $\mathrm{v}$ Ukrayini [Development of bioenergy potential in Ukraine]. Visnyk KHNAU. Seriya: Ekonomichni nauky - Bulletin of KhNAU. Series: Economic Sciences, 3, 229-238 [in Ukrainian].

16. Ofitsiynyy sayt Vinnytskoho natsionalnoho ahrarnoho universytetu Official website of Vinnytsia National Agrarian University (2021). Retrieved from: https://vsau.org/pro-universitet/nnvk-vseukraiinskij-naukovo-navchalnij-konsorczium [in Ukrainian]. 


\section{Відомості про авторів}

КАЛЕТНІК Григорій Миколайович - доктор економічних наук, професор, академік НААН України, завідувач кафедри адміністративного менеджменту та альтернативних джерел енергії, Вінницький національний аграрний університет (21008, м. Вінниця, вул. Сонячна, 3, e-mail: rector@vsau.org).

ПРИШЛЯК Наталя Вікторівна - кандидат економічних наук, доцент кафедри адміністративного менеджменту та альтернативних джерел енергії, Вінницький національний аграрний університет (21008, м. Вінниця, вул. Сонячна, 3, e-mail: pryshliaknatalia@vsau.vin.ua).

KALETNIK Grygorii - Doctor of Economic Sciences, Professor, Academician of NAAS of Ukraine, Head of the Department of Administrative Management and Alternative Energy Sources, Vinnytsia National Agrarian University (21008, Vinnytsia, 3 Soniachna str., e-mail: rector@vsau.org).

PRYSHLIAK Natalia - Candidate of Economic Sciences, Associate professor of the Administrative Management and Alternative Energy Sources Department, Vinnytsia National Agrarian University (21008, Vinnytsia, 3 Sonyachna str., e-mail: pryshliaknatalia@vsau.vin.ua).

КАЛЕТНИК Григорий Николаевич - доктор экономических наук, профессор, академик НАAН Украины, заведующий кафедрой административного менеджмента и альтернативных источников энергии, Винницкий национальный аграрный университет (21008, г. Винница, ул. Солнечная, 3, e-mail: rector@vsau.org).

ПРИШЛЯК Наталья Викторовна - кандидат экономических наук, доцент кафедры административного менеджмента и альтернативных источников энергии, Винницкий национальный аграрный университет (21008, г. Винница, ул. Солнечная, 3, e-mail: pryshliaknatalia@vsau.vin.ua). 